DOI:

UDC 678.02:621.365

V.F. Rozhkovskiy ${ }^{1}$, Cand. Tech. Sci., Senior lecturer

T.A. Manko ${ }^{1}$, Doctor of Tech. Sci., Professor

O.P. Romenska ${ }^{2}$, Engineer, olgaromenskaja@gmail.com

V.S. Zevako ${ }^{2}$, Cand. Tech. Sci., Head of department

${ }^{1}$ Oles Honchar Dnipro National University, Ukraine, Dnipro

${ }^{2}$ State Design Office «YUZHNOYE», Ukraine, Dnipro

\title{
MATHEMATICAL MODELING OF THE PROCESS OF HEATING A COMPOSITE CONSTRUCTION BY INFRARED RADIATION
}

In order to clarify the polymerization mode of a carbon fiber cylinder, mathematical modeling of the process of heating a composite structure (cylinder) by infrared radiation using the finite difference method was carried out. Using mathematical modeling, it was found that under given polymerization conditions, when exposed to infrared heating, the carbon fiber cylinder will reach a cured state within 120 minutes. The calculation data are confirmed by an analysis of the degree of polymerization of a carbon fiber fragment cut from a cylinder, cured by infrared heating. The degree of polymerization of carbon fiber using infrared radiation during curing is $95-96 \%$. merization

Key words: carbon fiber; cylinder; infrared heating; finite difference method; degree of poly-

В роботі, з метою уточнення режиму полімеризації вуглепластикового ичиліндру, проводилося математичне моделювання процесу нагрівання композитної конструкиії (циліндра) інфрачервоним випромінюванням при використанні методу кінцевих різниць. За допомогою математичного моделювання встановлено, що при заданих режимах полімеризації при впливі інфрачервоного випромінювання нагрівання вуглепластиковий ичиліндр протягом 120 хвилин досягне стану повної полімерізачії. Дані розрахунку підтверджені аналізом ступеня полімеризації фрагменту вуглепластика, вирізаного із ииліндру, щзо піддавали впливу інфрачервоного випромінювання. Значення ступеню полімеризації вуглепластика при використанні інфрачервоного випромінювання становить 95-96\%.

Ключові слова: вуглепластик; ииліндр; інфрачервоний нагрів; метод кінцевих різниць; ступінь полімеризащії.

\section{Problem's Formulation}

The existing production needs of the modern market impose ever-increasing demands on the characteristics of modern materials in order to expand their field of application in more severe and extreme conditions while at the same time searching for cost-effective production processes for producing finished products [1].

\section{Analysis of recent research and publications}

In aerospace engineering, polymer composite materials (PCM) based on carbon fibers are widely used. The unique properties of composite fiber materials with carbon fibers are determined primarily by the high mechanical properties of the fibers themselves [2]. The tensile strength of fillers - continuous single carbon fibers of the T800 type, according to the quality certificate, is about 5000 $6000 \mathrm{MPa}$, and the epoxy matrix-binder is $70-90 \mathrm{MPa}$. Thus, the theoretical (calculated) carbon fiber tensile strength is $\sigma_{\text {теор }}^{+}=3871 \mathrm{MPa}$. However, in practice, this value is at the level $\sigma_{\text {практ }}^{+}=1800$ $2500 \mathrm{MPa}$, which is $4555 \%$ of $\sigma_{\text {теор }}^{+}$.

Of great interest is the solution to the problems of increasing the strength of carbon plastics. These include:

- incomplete implementation of the strength properties of the carbon filler in the composition of carbon fiber; 
- the effect of the matrix on the strength of carbon fiber;

- coupling mechanism of the matrix and the filler.

Currently, research in the field of curing of dielectric materials, in particular binders in composites, using IR heating is very relevant [3].

It is known that the technological mode of manufacture is affected by the characteristics of the composite [4]. Traditionally, carbon fiber products are obtained by winding or laying on a forming mandrel with subsequent polymerization in special furnaces. Such methods are multistage, laborious and require high energy costs. There is a need for alternative technological modes of manufacturing carbon fiber.

The search for ways to improve traditional carbon fiber manufacturing methods and improve the implementation of the properties of the starting materials has led to the use of infrared (IR) heating [5]. Heating is proposed to be used in the process of winding and polymerization of carbon fiber. Due to the use of heating during winding, the viscosity of the matrix is kept constant, thereby ensuring uniform filling of the filler. During the time that the heating acts on the filler and the matrix, they cure. These processes occur due to the influence of energy quanta on the development of chemical reactions between macromolecules, that is, photochemical processes of interaction arise [6]. In order to cure and relieve internal stresses in carbon fiber, it is proposed to apply IR heating during polymerization. Thus, the use of IR heating can reduce the manufacturing time, and also due to a more uniform heating, the uniformity of the cured carbon fiber microstructure increases [7].

\section{Formulation of the study purpose}

In order to clarify the polymerization mode of a carbon fiber cylinder, mathematical modeling of the process of heating a composite structure (cylinder) by infrared radiation using the finite difference method was carried out.

\section{Presenting main material}

To apply the finite difference method, we simplify the problem as follows. We will consider the two-dimensional problem, therefore, we believe that along the $z$ coordinate (along the cylinder axis) no changes occur. We will also assume that the structure under consideration consists of two parts, a composite and a mandrel, which are uniform in parameters: $c$ - density of the substance and $C$ - heat capacity. We will consider these parameters with index 1 for the composite and with index 2 for the mandrel.

We consider a composite anisotropic in thermal conductivity with thermal conductivity coefficients $\lambda_{r 1}$ in the direction of the radial coordinate and $\mathrm{c}_{1}$ in the direction of the angular coordinate. We consider the mandrel isotropic in thermal conductivity with a thermal conductivity coefficient of $\lambda_{2}$. We also consider these coefficients constant within their bodies.

The temperature $T$ at each point of the composite under the influence of IR heating is described by such equations

$$
\begin{gathered}
-\left(\frac{\partial s}{\partial \tau}+\omega \frac{\partial s}{\partial \varphi}\right)=a_{1} s \sqrt{T} \exp \frac{-E_{a}}{R T}+C s q_{1} ; \\
\frac{\partial T}{\partial \tau}+\omega \frac{\partial T}{\partial \varphi}=\frac{1}{\rho_{1} c_{1}}\left[\frac{1}{e^{2 z}}\left(\lambda_{r 1} \frac{\partial^{2} T}{\partial z^{2}}+\lambda_{\varphi 1} \frac{\partial^{2} T}{\partial \varphi^{2}}\right)+q_{1}+\frac{\partial s}{\partial \xi}\right],
\end{gathered}
$$

where $s$ is the degree of polymerization at each point of the composite, a function that takes the value of unity at the beginning of polymerization to zero during complete polymerization; $\omega-$ angular velocity of rotation of the cylinder; $\tau$ - time; $\varphi$ is the angular coordinate; $z$ is the coordinate along the radius of the cylinder associated with the radius $r$ by the formula $z=\ln r$; $\xi$ is the coordinate associated with the coordinates $\tau$ and $\varphi$ by the formula $\xi=0,5(\tau+\varphi / \omega) ; a_{1}$ is the rate constant of the polymerization reaction, showing the reaction rate at the maximum concentration of molecules that enter into the reaction; $R$ is the universal gas constant $(8.31 \mathrm{~J} / \mathrm{K}) ; E_{a}$ is the activation energy of the molecule; $C$ is a constant indicating which part of the radiation leads to the polymerization reaction; $q_{1}$ is the power of IR radiation in the composite unit volume calculated by the location of the IR fixtures. Formula (1) is a 
consequence of the Arrhenius equation describing the polymerization process, and formula (2) is the equation thermal conductivity.

The temperature $T$ at each point of the mandrel under the influence of IR heating is described by the heat equation

$$
\frac{\partial T}{\partial \tau}+\omega \frac{\partial T}{\partial \varphi}=\frac{1}{\rho_{2} c_{2}}\left[\frac{\lambda_{2}}{e^{2 z}}\left(\frac{\partial^{2} T}{\partial z^{2}}+\frac{\partial^{2} T}{\partial \varphi^{2}}\right)+q_{2}\right],
$$

where $q_{2}$ is the infrared radiation power in a unit volume calculated by the location of the IR luminaires.

The boundary conditions were adopted as follows. On the outer surface of the cylinder, there is both heat exchange with the surrounding air and radiant heat transfer, obeying the Stefan-Boltzmann law [8]. The boundary condition here has the form

$$
\left.\lambda_{r 1} \frac{\partial T}{\partial z}\right|_{z=z_{1}}=e^{z_{1}}\left(\alpha_{1}+\alpha_{\pi}\right)\left(T-T_{c}\right),
$$

where $z_{1}$ is the quantity associated with the radius of the outer surface $r_{1}$ of the cylinder according to the formula $z_{1}=\ln r_{1} ; \alpha_{1}$ is the known coefficient of convective heat transfer for the outer surface; $\alpha_{J}$ is the radiant heat transfer coefficient depending on the body temperature $T$, the environment $T_{c}$, and the degree of blackness $\varepsilon$ the formula

$$
\alpha_{n}=5,67 \cdot 10^{-8} \varepsilon\left(T+T_{c}+546\right)\left[(T+273)^{2}+\left(T_{c}+273\right)^{2}\right] .
$$

On the inner surface of the composite cylinder, only heat exchange with the surrounding air takes place:

$$
\left.\lambda_{2} \frac{\partial T}{\partial z}\right|_{z=z_{0}}=e^{z_{0}} \alpha_{2}\left(T-T_{c}\right),
$$

where $z_{0}$ is the value associated with the radius of the inner surface $r_{0}$ of the cylinder according to the formula $z_{0}=\ln r_{0} ; \alpha_{2}$ - convective heat transfer coefficient for the inner surface. At the boundary between the mandrel and the composite cylinder, contact heat transfer conditions apply.

$$
\frac{\partial T}{\partial \tau}+\omega \frac{\partial T}{\partial \varphi}=\frac{1}{2 \rho_{1} c_{1}}\left[\frac{1}{e^{2 z_{2}}}\left(\lambda_{r 1} \frac{\partial^{2} T}{\partial z^{2}}+\lambda_{\varphi 1} \frac{\partial^{2} T}{\partial \varphi^{2}}\right)+q_{1}+\frac{\partial s}{\partial \xi}\right]+\frac{1}{2 \rho_{2} c_{2}}\left[\frac{\lambda_{2}}{e^{2 z_{2}}}\left(\frac{\partial^{2} T}{\partial z^{2}}+\frac{\partial^{2} T}{\partial \varphi^{2}}\right)+q_{2}\right],
$$

where $z_{2}$ - the value corresponding to the radius of the boundary $r_{2}$ according to the formula $z_{2}=\ln r_{2}$.

Equations (1) - (3) together with the corresponding boundary conditions form a boundary value problem. The unknowns in this problem are the quantities $s$ and $T$, and the remaining quantities are considered known.

To solve the problem, we cover the region of the cylinder section, which is a ring, with a regular grid (Fig. 1). To do this, we determine the radius step in the composite part $h_{z 1}$, the radius step in the mandrel $h_{z 2}$, the angle step $h_{\mathrm{L}}$ and the time step $h_{\phi}$, as well as the corresponding coordinates of the grid nodes according to the formulas

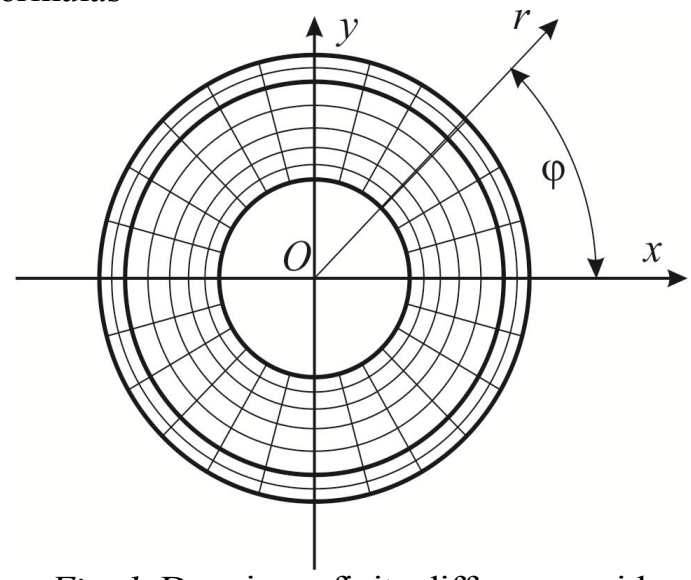

Fig. 1. Drawing a finite difference grid 


$$
\begin{aligned}
& i=1,2, \ldots, N+1 ; \quad h_{z 1}=\frac{z_{1}-z_{2}}{N} ; \quad z_{i}=z_{2}+h_{z 1}(i-1) ; \\
& j=1,2, \ldots, P+1 ; \quad h_{z 2}=\frac{z_{2}-z_{0}}{P} ; \quad z_{j}=z_{0}+h_{z 2}(j-1) ; \\
& m=1,2, \ldots, M ; \quad h_{\varphi}=\frac{2 \pi r}{M} ; \quad \varphi_{m}=h_{\varphi} m ; \\
& k=1,2, \ldots, L ; \quad \tau_{k}=h_{\tau} k .
\end{aligned}
$$

where $N, P$ - the number of partitions in the radial direction for the composite and mandrel, respectively; $M$ - the number of partitions in the radial direction for the composite and mandrel, respectively; $L$ - number of time slots.

The last point with $j=\mathrm{P}+1$ for the mandrel coincides with the first point with $i=1$ for the composite

As a result of replacing the partial differential equation by difference relations, a system of algebraic equations is obtained. This system is nonlinear due to the nonlinearity of equation (1). To solve the resulting system of nonlinear equations, the Gauss-Seidel iterative method was used. This method is inferior to some direct methods, for example, the sweep method, for problems in a linear formulation of the solution speed. But nonlinear problems are solved by this method at almost the same speed as linear ones; therefore, when solving nonlinear problems, the advantages of direct methods are lost. The Gauss-Seidel method is easily programmable [9]. It is well suited for solving problems of unsteady heat conduction with a time step, since for the initial approximation of the solution at the next time step, we can take the solution obtained in the previous step.

In order to ensure the stability of the computing process, an implicit scheme of the finite difference method was used. An implicit scheme is a finite-difference discretization scheme in which, when moving from the time layer $k$ to the time layer $k+1$, the sampling for spatial variables is carried out for the layer $k+1$.Discretization for spatial variables is as follows.

$$
\begin{aligned}
& s(\xi)=\exp \left[-\int_{0}^{\xi}\left(a_{1} \sqrt{T} \exp \frac{-E_{a}}{R T}+C q_{1}\right) d \xi\right]= \\
& =\exp \left[-a_{1} \int_{0}^{\xi} \sqrt{T} \exp \frac{-E_{a}}{R T} d \xi\right] \exp \left[-C q_{1} \int_{0}^{\xi} d \xi\right]
\end{aligned}
$$

If the value of $s\left(\xi_{1}\right)$ is known for a certain value of $\xi_{1}$, then the transition from $\xi_{1} k \xi$ is carried out according to the formula

$$
s(\xi)=s\left(\xi_{1}\right) \exp \left[-a_{1} \int_{\xi_{1}}^{\xi} \sqrt{T} \exp \frac{-E_{a}}{R T} d \xi\right] \exp \left[-C q_{1} \int_{\xi_{1}}^{\xi} d \xi\right] .
$$

We choose the value $\xi$ on the current temporary layer, and the value $\xi_{1}-$ on the previous one. We calculate the integrals by passing from curvilinear integrals of the first kind to the usual definite ones. To do this, we pass from the variable $\xi$ to the variable $\tau$, considering it independent.

$$
\begin{aligned}
& \int_{\xi_{1}}^{\xi} \sqrt{T(\xi)} \exp \frac{-E_{a}}{R T(\xi)} d \xi=\int_{\tau_{1}}^{\tau} \sqrt{T(\tau, \varphi(\tau))} \exp \frac{-E_{a}}{R T(\tau, \varphi(\tau))} \sqrt{1+\left(\frac{d \varphi(\tau)}{d \tau}\right)^{2}} d \tau ; \\
& \int_{\xi_{1}}^{\xi} d \xi=\int_{\tau_{1}}^{\tau} \sqrt{1+\left(\frac{d \varphi(\tau)}{d \tau}\right)^{2}} d \tau,
\end{aligned}
$$

where $\tau_{1}$ - time corresponding to the previous temporary layer; $d \varphi(\tau)=d \tau$.

The value under the integral is calculated as follow

$$
\sqrt{1+\left(\frac{d \varphi(\tau)}{d \tau}\right)^{2}}=\sqrt{1+\omega^{2}} .
$$

Certain integrals are calculated using the trapezoid formula 


$$
\begin{aligned}
& \int_{\tau_{1}}^{\tau} \sqrt{T(\tau, \varphi(\tau))} \exp \frac{-E_{a}}{R T(\tau, \varphi(\tau))} \sqrt{1+\omega^{2}} d \tau= \\
& =\frac{1}{2}\left(\sqrt{T\left(\tau_{1}, \varphi\left(\tau_{1}\right)\right)} \exp \frac{-E_{a}}{R T\left(\tau_{1}, \varphi\left(\tau_{1}\right)\right)}+\sqrt{T(\tau, \varphi(\tau))} \exp \frac{-E_{a}}{R T(\tau, \varphi(\tau))}\right) h_{\tau} \sqrt{1+\omega^{2}} \\
& \int_{\tau_{1}}^{\tau} \sqrt{1+\omega^{2}} d \tau=\frac{1}{2}\left(\sqrt{1+\omega^{2}}+\sqrt{1+\omega^{2}}\right) h_{\tau}=h_{\tau} \sqrt{1+\omega^{2}}
\end{aligned}
$$

The value $\mathrm{T}(\tau, \varphi(\tau))$ is taken as $T_{i, m}^{k+1}$ - the temperature at the grid node with the spatial coordinates $i$ and $m$ on the time layer with the number $k+1$, and the corresponding value $T\left(\tau_{1}, \varphi_{1}\left(\tau_{1}\right)\right)$ which we denote as $T_{i, m, \omega}^{k}$, is calculated by linear interpolation using the closest values on the previous temporary layer:

$$
\begin{aligned}
& T_{i, m, \omega}^{k}=T\left(\tau_{1}, \varphi\left(\tau_{1}\right)\right)=T_{i, m-m_{2}}^{k}\left(\frac{\omega h_{\tau}}{h_{\varphi}}-m_{1}\right)+T_{i, m-m_{1}}^{k}\left(m_{2}-\frac{\omega h_{\tau}}{h_{\varphi}}\right) ; \\
& m_{1}=\text { floor }\left(\frac{\omega h_{\tau}}{h_{\varphi}}\right) ; \quad m_{2}=\text { ceil }\left(\frac{\omega h_{\tau}}{h_{\varphi}}\right),
\end{aligned}
$$

where floor - rounding down function; ceil — rounding up function.

We denote by the $s_{i, m}^{k}$ degree of cure of the composite at the grid node with the spatial coordinates $i$ and $m$ on the time layer with number $\mathrm{k}$. The discretization of the quantity $\mathrm{s}\left(\xi_{1}\right)$ is carried out similarly to the quantity $\mathrm{T}\left(\xi_{1}\right)=\mathrm{T}\left(\tau_{1}, \varphi_{1}\left(\tau_{1}\right)\right)$, which gives

$$
s\left(\xi_{1}\right)=s_{i, m, \omega}^{k}=s_{i, m-m_{2}}^{k}\left(\frac{\omega h_{\tau}}{h_{\varphi}}-m_{1}\right)+s_{i, m-m_{1}}^{k}\left(m_{2}-\frac{\omega h_{\tau}}{h_{\varphi}}\right) .
$$

Discretization of equation (1) gives

$$
\begin{aligned}
& s_{i, m, \omega}^{0}=1 ; \\
& s_{i, m}^{k+1}=s_{i, m, \omega}^{k} \exp \left\{-h_{\tau} \sqrt{1+\omega^{2}}\left[\frac{1}{2} a_{1}\left(\sqrt{T_{i, m, \omega}^{k}} \exp \frac{-E_{a}}{R T_{i, m, \omega}^{k}}+\sqrt{T_{i, m}^{k+1}} \exp \frac{-E_{a}}{R T_{i, m}^{k+1}}\right)+C q_{1}\right]\right\},
\end{aligned}
$$

where $T_{i, m}^{k}$ - temperature at the grid node with spatial coordinates $i$ and $m$ on the temporary layer with number $k ; s_{i, m}^{k}$ - the degree of cure of the composite at the grid node with the spatial coordinates $i$ and $m$ on the temporary layer with number $k ; T_{i, m, \omega}^{k}$ and $s_{i, m, \omega}^{k}-$ the values of the corresponding quantities obtained by linear interpolation from the two closest values from the grid.

Values $T_{i, m, \omega}^{k}$ and $s_{i, m, \omega}^{k}$ are calculated on formulas

$$
\begin{aligned}
& T_{i, m, \omega}^{k}=T_{i, m-m_{2}}^{k}\left(\frac{\omega h_{\tau}}{h_{\varphi}}-m_{1}\right)+T_{i, m-m_{1}}^{k}\left(m_{2}-\frac{\omega h_{\tau}}{h_{\varphi}}\right) ; \\
& s_{i, m, \omega}^{k}=s_{i, m-m_{2}}^{k}\left(\frac{\omega h_{\tau}}{h_{\varphi}}-m_{1}\right)+s_{i, m-m_{1}}^{k}\left(m_{2}-\frac{\omega h_{\tau}}{h_{\varphi}}\right) ; \\
& m_{1}=\text { floor }\left(\frac{\omega h_{\tau}}{h_{\varphi}}\right) ; \quad m_{2}=\operatorname{ceil}\left(\frac{\omega h_{\tau}}{h_{\varphi}}\right),
\end{aligned}
$$


where floor - rounding down function; ceil - rounding up function.

The discretized equations (2) and (3) look like this

$$
\left.\begin{array}{l}
\frac{T_{i, m}^{k+1}-T_{i, m}^{k}}{h_{\tau}}+\omega \frac{T_{i, m}^{k+1}-T_{i, m-1}^{k+1}}{h_{\varphi}}=\frac{1}{\rho_{1} c_{1}}\left[\begin{array}{l}
\frac{1}{e^{2 z_{i}}}\left(\lambda_{r 1} \frac{T_{i+1, m}^{k+1}-2 T_{i, m}^{k+1}+T_{i-1, m}^{k+1}}{h_{z 1}^{2}}+\lambda_{\varphi l} \frac{T_{i, m+1}^{k+1}-2 T_{i, m}^{k+1}+T_{i, m-1}^{k+1}}{h_{\varphi}^{2}}\right) \\
+q_{1, i, m}+\frac{s_{i, m}^{k+1}-s_{i, m}^{k}+\omega \frac{s_{i, m}^{k+1}-s_{i, m-1}^{k+1}}{h_{\varphi}}}{h_{\varphi}}
\end{array}\right] ; \\
\frac{T_{j, m}^{k+1}-T_{j, m}^{k}}{h_{\tau}}+\omega \frac{T_{j, m}^{k+1}-T_{j, m-1}^{k+1}}{h_{\varphi}}=\frac{1}{\rho_{2} c_{2}}\left[\frac{\lambda_{2}}{e^{2 z_{j}}}\left(\frac{T_{j+1, m}^{k+1}-2 T_{j, m}^{k+1}+T_{j-1, m}^{k+1}}{h_{z 2}^{2}}+\frac{T_{j, m+1}^{k+1}-2 T_{j, m}^{k+1}+T_{j, m-1}^{k+1}}{h_{\varphi}^{2}}\right)+q_{2, j, m}\right.
\end{array}\right],
$$

where $T_{i, m}^{k}$ - temperature at the grid node with spatial coordinates $\mathrm{i}$ and $\mathrm{m}$ on the time layer with number $k ; s_{i, m}^{k}$ - the degree of cure of the composite in the grid node with spatial coordinates $i$ and $m$ at temporary layer with number $k$.

At boundary nodal points, finite difference relations are written as follows. On the bottom edge of the mandrel or composite in the absence of a mandrel

$$
T_{1, m}^{k+1}=\frac{T_{c}+T_{2, m}^{k+1} \beta_{2}+0,5 Q_{2,1, m}}{1+\beta_{2}} ; T_{1, m}^{k+1}=\frac{T_{c}+T_{2, m}^{k+1} \beta_{2}+0,5 Q_{1,1, m}}{1+\beta_{2}} ;
$$

where $\beta_{2}=\frac{\lambda_{r 1}}{\alpha_{2} h_{z 1} e^{z_{2}}}$ is for composite without mandrel and $\beta_{2}=\frac{\lambda_{2}}{\alpha_{2} h_{z 2} e^{z_{0}}}$ is for mandrel.

On the top edge of the composite

$$
T_{N+1, m}^{k+1}=\frac{T_{c}+T_{N, m}^{k+1} \beta_{1}+0,5\left(Q_{1, N+1, m}+S_{N+1, m}^{k+1}-S_{N+1, m}^{k}+\Omega\left(S_{i, m}^{k+1}-S_{i, m-1}^{k+1}\right)\right)}{1+\beta_{1}},
$$

where $\beta_{1}=\frac{\lambda_{r 1}}{\left(\alpha_{1}+\alpha_{l}\right) h_{z, 1} e^{z_{N+1}}}, \alpha_{\Omega}=5,67 \cdot 10^{-8} \varepsilon\left(T_{N+1, m}^{k+1}+T_{c}+546\right)\left[\left(T_{N+1, m}^{k+1}+273\right)^{2}+\left(T_{c}+273\right)^{2}\right]$.

We derive the relations for the boundary conditions between the mandrel and the composite. To do this, we carry out finite-difference discretization of the equation.

Second derivative $\frac{\partial^{2} T}{\partial z^{2}}$ is shown as follow

$$
\begin{aligned}
& \frac{\partial^{2} T}{\partial z^{2}}=\frac{\frac{T_{2, m}^{k+1}-T_{1, m}^{k+1}}{h_{z 1}}-\frac{T_{1, m}^{k+1}-T_{P, m}^{k+1}}{h_{z 2}}}{\frac{h_{z 1}+h_{z 2}}{2}}=2 \frac{h_{z 2}\left(T_{2, m}^{k+1}-T_{1, m}^{k+1}\right)-h_{z 1}\left(T_{1, m}^{k+1}-T_{P, m}^{k+1}\right)}{h_{z 1} h_{z 2}\left(h_{z 1}+h_{z 2}\right)} . \\
& =\frac{2 T_{2, m}^{k+1}}{h_{z 1}\left(h_{z 1}+h_{z 2}\right)}+\frac{2 T_{P, m}^{k+1}}{h_{z 2}\left(h_{z 1}+h_{z 2}\right)}-\frac{2 T_{1, m}^{k+1}}{h_{z 1} h_{z 2}}
\end{aligned}
$$

On the border between the mandrel and the composite 


$$
\begin{aligned}
& \frac{T_{1, m}^{k+1}-T_{1, m}^{k}}{h_{\tau}}+\omega \frac{T_{1, m}^{k+1}-T_{1, m-1}^{k+1}}{h_{\varphi}}=\left(\frac{\lambda_{r 1}}{2 q_{1} c_{1} e^{2 z_{2}}}+\frac{\lambda_{2}}{2 p_{2} c_{2} e^{2 z_{2}}}\right)\left(\frac{2 I_{2 m}^{k+1}}{h_{21}\left(h_{z 1}+h_{z 2}\right)}+\frac{2 I_{P, m}^{k+1}}{h_{z 2}\left(h_{z 1}+h_{z 2}\right)} \frac{2 I_{1, m}^{k+1}}{h_{z 1} h_{z 2}}\right)+ \\
& \left.+\left(\frac{\lambda_{\varphi 1}}{2 \rho_{1} c_{1} e^{z_{2}}}+\frac{\lambda_{2}}{2 \rho_{2} c_{2} e^{2 z_{2}}}\right)\left(\frac{T_{1, m+1}^{k+1}-2 T_{1, m}^{k+1}+T_{1, m-1}^{k+1}}{h_{\varphi}^{2}}\right)+0,5\left(Q_{1,1, m}+Q_{1, m}+S_{1, m}^{k+1}-S_{1, m}^{k}+\Omega_{4} S_{1, m}^{k+1}-S_{1, m-1}^{k+1}\right)\right)=
\end{aligned}
$$

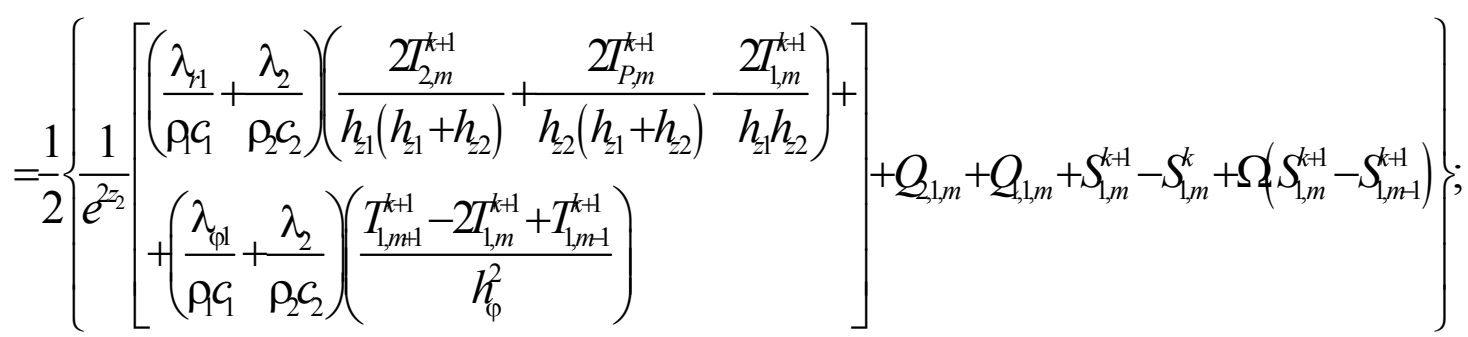

where is the value $T_{P, m}^{k+1}$ refer to the mandrel, and the values $T_{1, m}^{k+1}$ и $T_{2, m}^{k+1}$ - to composite.

The algorithm for solving the problem using the Gauss-Seidel method is as follows. Denote the solution for the degree of cure on $(k+1)$ time layer as

$$
U_{n, m}=S_{n, m}^{k+1},
$$

and the solution for temperature on $(k+1)$ temporary layer as

$$
V_{n, m}=T_{n, m}^{k+1} \text {. }
$$

Herein $n$ means general index for $i$ and $j$. To get solutions of $U_{n, m}$ and $V_{n, m}$, it is needed to do the following operations. As initial approximations of solutions to $(k+1)$ temporary layer $U_{n, m}^{0}$ and $V_{n, m}^{0}$ decisions are made on $k$ temporary layer. If approximations $U_{n, m}^{l}$ and $V_{n, m}^{l}$ are known, then to search for approximations $U_{n, m}^{l+1}$ and $V_{n, m}^{l+1}$ all points of the cylinder are bypassed, primarily from the inside out, and secondly along the circumferential coordinate. At each point of the cylinder, the values $U_{n, m}^{l+1}$ and $V_{n, m}^{l+1}$ are calculated. The formula for calculating this value depends on whether the given point is internal or boundary. Formulas for internal points are derived by replacing the values in accordance with the notation, resolving the obtained equations with respect to $U_{n, m}^{l+1}$ and $V_{n, m}^{l+1}$ and arrangement of superscripts at $U_{n, m}$ and $V_{n, m}$ according to whether the new value of a given quantity is known, giving preference to the new. These formulas are written as follows

$$
\begin{gathered}
U_{i, m}^{l+1}=S_{i, m, \omega}^{k} \exp \left\{-h_{\tau} \sqrt{1+\omega^{2}}\left[\frac{1}{2} a_{1}\left(\sqrt{T_{i, m, \omega}^{k}} \exp \frac{-E_{a}}{R T_{i, m, \omega}^{k}}+\sqrt{V_{i, m}^{l}} \exp \frac{-E_{a}}{R V_{i, m}^{l}}\right)+C Q_{1, i, m} \rho_{1} c_{1}\right]\right\} ; \\
V_{i, m}^{t+1}=\frac{Q_{1, i, m}+\frac{1}{e^{2 z_{i}} \rho_{1} \mathcal{C}_{1}}\left(\lambda_{r 1} \frac{V_{i+1, m}^{l}+V_{i-1, m}^{l+1}}{h_{z 1}^{2}}+\lambda_{\varphi 1} \frac{V_{i, m+1}^{l}+V_{i, m-1}^{l+1}}{h_{\varphi}^{2}}\right)+\omega \frac{V_{i, m-1}^{l+1}}{h_{\varphi}}+\frac{T_{i, m}^{k}}{h_{\tau}}+U_{i, m}^{t+1}-S_{i, m}^{k}+\Omega\left(U_{i, m}^{+1}-U_{i, m-1}^{t+1}\right)}{\frac{1}{h}+\frac{\omega}{h_{\varphi}}+\frac{2}{e^{2 z_{i}} \rho_{1} \mathcal{C}_{1}}\left(\frac{\lambda_{r 1}}{h_{z 1}^{2}}+\frac{\lambda_{\varphi 1}}{h_{\varphi}^{2}}\right)} ;
\end{gathered}
$$




$$
V_{j, m}^{l+1}=\frac{Q_{2, j, m}+\frac{\lambda_{2}}{e^{2 z_{j}} \rho_{2} c_{2}}\left(\frac{V_{j+1, m}^{l}+V_{j-1, m}^{l+1}}{h_{z 2}^{2}}+\frac{V_{j, m+1}^{l}+V_{j, m-1}^{l+1}}{h_{\varphi}^{2}}\right)+\omega \frac{V_{j, m-1}^{l+1}}{h_{\varphi}}+\frac{T_{j, m}^{k}}{h_{\tau}}}{\frac{1}{h_{\tau}}+\frac{\omega}{h_{\varphi}}+\frac{2 \lambda_{2}}{e^{2 z_{j}} \rho_{2} c_{2}}\left(\frac{1}{h_{z 2}^{2}}+\frac{1}{h_{\varphi}^{2}}\right)} .
$$

Formulas for boundary nodes are derived similarly to formulas for internal nodes. The formulas for the point of the outer surface of the composite are as follows

$$
\begin{gathered}
\alpha_{l, N+1, m}^{l}=5,67 \cdot 10^{-8} \varepsilon\left(V_{N+1, m}^{l}+T_{c}+546\right)\left[\left(V_{N+1, m}^{l}+273\right)^{2}+\left(T_{c}+273\right)^{2}\right] ; \\
\beta_{1, N+1, m}^{l}=\frac{\lambda_{r 1}}{\left(\alpha_{1}+\alpha_{\Omega, N+1, m}^{l}\right) h_{z, 1} e^{z_{N+1}}} ; \\
V_{N+1, m}^{l+1}=\frac{T_{c}+V_{N, m}^{l+1} \beta_{1, N+1, m}^{l}+0,5\left(Q_{1, N+1, m}+U_{N+1, m}^{l+1}-S_{N+1, m}^{k}+\Omega\left(U_{N+1, m}^{l+1}-U_{N+1, m-1}^{l+1}\right)\right)}{1+\beta_{1, N+1, m}^{l}} .
\end{gathered}
$$

The formulas for the point on the inner surface of the composite in the absence of a mandrel look like this

$$
\begin{gathered}
\beta_{2}=\frac{\lambda_{r 1}}{\alpha_{2} h_{z 1} e^{z_{2}}}, \\
V_{1, m}^{l+1}=\frac{T_{c}+V_{2, m}^{l} \beta_{2}+0.5\left(Q_{1,1, m}+U_{1, m}^{l+1}-S_{1, m}^{k}+\Omega\left(U_{1, m}^{l+1}-U_{1, m-1}^{l+1}\right)\right)}{1+\beta_{2}} .
\end{gathered}
$$

The formulas for the point on the inner surface of the mandrel are as follows

$$
\begin{gathered}
\beta_{2}=\frac{\lambda_{2}}{\alpha_{2} h_{z 2} e^{z_{0}}}, \\
V_{1, m}^{l+1}=\frac{0,5 Q_{2,1, m}+T_{c}+V_{2, m}^{l} \beta_{2}}{1+\beta_{2}} .
\end{gathered}
$$

The formula for the common points of the mandrel and the composite is as follow:

$$
\begin{aligned}
& V_{1, m}^{l+1}=\left[\frac{1}{h_{\tau}}+\frac{\omega}{h_{\varphi}}+\frac{1}{e^{2 z_{2}}}\left[\frac{1}{\rho_{1} c_{1}}\left(\frac{\lambda_{\varphi 1}}{h_{\varphi}^{2}}+\frac{\lambda_{r 1}}{h_{z 1} h_{z 2}}\right)+\frac{\lambda_{2}}{\rho_{2} c_{2}}\left(\frac{1}{h_{\varphi}^{2}}+\frac{1}{h_{z 1} h_{z 2}}\right)\right]\right]^{-1} \times \\
& \times\left[0,5\left(Q_{1,1, m}+Q_{2,1, m}+U_{1, m}^{l+1}-S_{1, m}^{k}+\Omega\left(U_{1, m}^{l+1}-U_{1, m-1}^{l+1}\right)\right)+\omega \frac{V_{1, m-1}^{l+1}}{h_{\varphi}}+\frac{T_{1, m}^{k}}{h_{\tau}}+\right. \\
& \left.+\frac{1}{2 e^{2 z_{2}}}\left[\frac{V_{1, m+1}^{l}+V_{1, m-1}^{l+1}}{h_{\varphi}^{2}}\left(\frac{\lambda_{\varphi 1}}{\rho_{1} c_{1}}+\frac{\lambda_{2}}{\rho_{2} c_{2}}\right)+\frac{2}{h_{z 1}+h_{z 2}}\left(\frac{\lambda_{r 1}}{\rho_{1} c_{1}}+\frac{\lambda_{2}}{\rho_{2} c_{2}}\right)\left(\frac{V_{2, m}^{l}}{h_{z 1}}+\frac{V_{P, m}^{l+1}}{h_{z 2}}\right)\right]\right] .
\end{aligned}
$$

In addition to the values $V_{s, m}^{l+1}$ when traversing nodes, values are also calculated 


$$
\begin{aligned}
& S=\sum_{s=1}^{N+P+2} \sum_{m=1}^{M}\left|V_{s, m}^{l+1}-V_{s, m}^{l}\right| ; \\
& S_{d}=\sum_{s=1}^{N+P+2} \sum_{m=1}^{M}\left|V_{s, m}^{l+1}\right|,
\end{aligned}
$$

which serve to evaluate the accuracy of the solution.

Fig. 2 shows the results of the calculation using the finite difference method of the cylinder on the mandrel with the following initial data: $r_{1}=0,07225 \mathrm{~m} ; r_{2}=0,073 \mathrm{~m} ; b=0,08 \mathrm{~m} ; \omega=0,7 \mathrm{c}^{-1}$; $\lambda=0,371 \mathrm{Wt} / \mathrm{m}^{2} \cdot \operatorname{deg} ; c=1,08 \mathrm{~kJ} / \mathrm{kg} \operatorname{deg} ; c=1450 \mathrm{~kg} / \mathrm{m}^{3} ; \mathrm{e}=0,7 ; \delta_{\mathrm{k} 1}=40 \mathrm{Wt} / \mathrm{m}^{2} \cdot \operatorname{deg} ; \delta_{\mathrm{k} 2}=33 \mathrm{Wt} / \mathrm{m}^{2} \cdot \operatorname{deg} ;$ $E=1,3 \mathrm{MeV} ; I=3 \mathrm{~mA} / \mathrm{m}$; $p=11 / \mathrm{m}$. Sampling parameters $N=5 ; M=32 ; L=1000$.

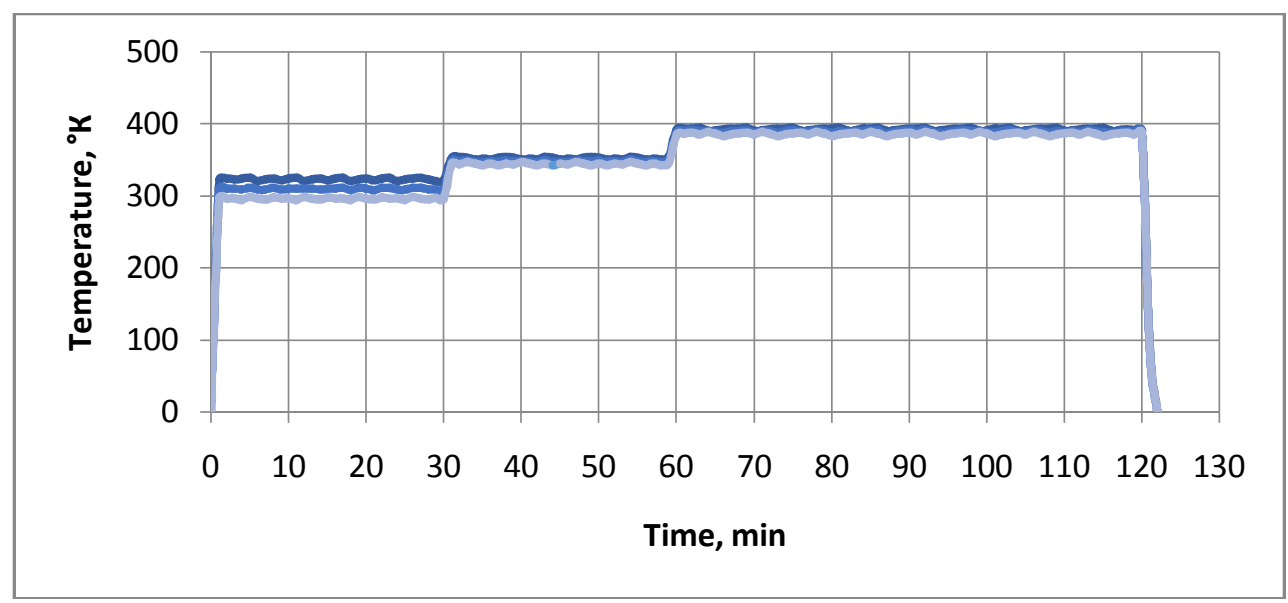
IR heating

Fig. 2. The temperature distribution on the surface of the cylinder from the time of exposure to

In the above figure, the red lines indicate the maximum and minimum temperatures for the cylinder surface obtained by the finite difference method, the blue lines represent the analytical solution of the problem for a point on the lower surface of the cylinder rotating with the cylinder. With this discretization, the error of the numerical solution is at a time of 120 minutes $11 \%$. The error of the numerical solution was calculated by the formula

$$
\frac{T_{1}-T_{2}}{T_{c}} \times 100 \%,
$$

where $T_{1}-T_{2}=323-298=25 \mathrm{~K}$ - maximum cylinder temperature difference between analytical and numerical solutions; $T_{\mathrm{c}}=324^{\circ} \mathrm{K}$ - average cylinder temperature

Figure 3 shows a graph of the degree of cure of the carbon fiber cylinder on the time of exposure to IR heating. If we take $s=0.1$, then the upper graph almost reached this value in 240 minutes.

Based on the presented figures, it follows that under the given polymerization conditions when exposed to IR heating, the carbon fiber cylinder will reach a cured state within 240 minutes.

This calculation was confirmed by analyzing the degree of polymerization of a carbon fiber fragment cut from a cylinder that was cured by IR heating. Determining the degree of polymerization is one of the criteria confirming the correct choice of the polymerization mode for carbon plastics.

Table 1 shows the results of determining the degree of polymerization of carbon fiber made from carbon fiber using standard technology (using convective heating) and using infrared radiation. 


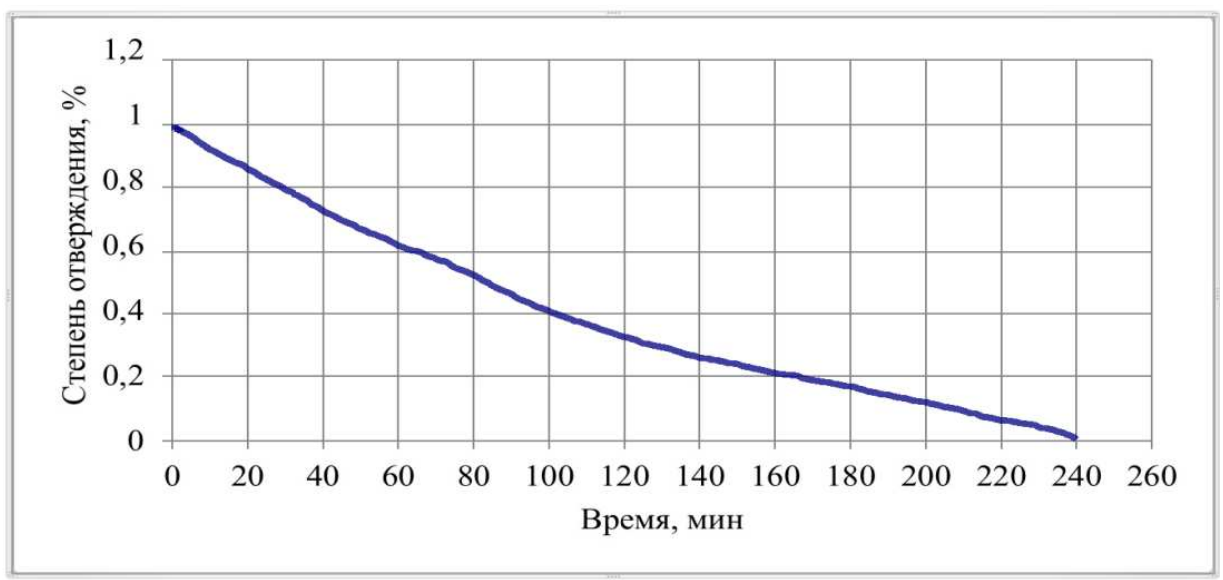

Fig. 3. Dependence of curing cylinder degree on the time of exposure to IR heating

Table 1. Carbon fiber polymerization degree

\begin{tabular}{|c|c|}
\hline Carbon plastic type & Polymerization degree, $\%$ \\
\hline $\begin{array}{l}\text { Carbon fiber manufactured using standard } \\
\text { technology }\end{array}$ & $94-96$ \\
\hline Carbon fiber manufactured using IR radiation & $95-96$ \\
\hline
\end{tabular}

The calculated degree of polymerization of carbon plastics is in the range from 94 to $96 \%$, which is sufficient to decide on the suitability of the manufactured carbon fiber. The use of IR radiation during the curing of carbon fiber has allowed to obtain a high degree of polymerization with a significant reduction in the polymerization time of the carbon fiber cylinder.

\section{Conclusion}

1. The task of temperature distribution in a rotating thin-walled cylinder with a thickness of the order of $1 \mathrm{~mm}$, subjected to infrared radiation during curing, is formulated.

2. Computational experiments have been carried out to study thermal processes in carbon fiber reinforced plastic and it has been established that the selected infrared curing mode makes it possible to obtain a fully cured cylinder.

3. The established dependences make it possible to take into account the change in the physicomechanical characteristics of the products during storage and operation.

4. The correct choice of the infrared curing mode of the carbon fiber cylinder is confirmed by the analysis of the degree of polymerization of the finished carbon fiber.

\section{Reference}

[1] Mihailin Yu.O. (2008). Konstruktsionnyye polimernyye kompozitsionnyye materialy [Structural Polymer Composite Materials].

[2] Kovalenko V.A., Kondratyev A.V. (2011). Primeneniye polimernykh kompozitsionnykh materialov $\mathrm{v}$ izdeliyakh raketno-kosmicheskoy tekhniki kak rezerv povysheniya yeye massovoy i funktsional'noy effektivnosti [The use of polymer composite materials in rocket and space technology products as a reserve for increasing its mass and functional efficiency] // Aviatsionnokosmicheskaya tekhnika i tekhnologiya, №5 (82), p.14-20

[3] Tsaplin A.I. Bochkarev S.V. (1980). Nestatsionarnoye temperaturnoye pole vrashchayushchegosya stekloplastikovogo tsilindra, obluchennogo parallel'nym elektronnym puchkom [Unsteady temperature field of a rotating fiberglass cylinder irradiated with a parallel electron beam] // Mechanics of composite materials, №2, p. 304-307. 
[4] Komkov M.A., Tarasov V.A. (2014). Vliyaniye vyazkosti svyazuyushchego v propitochnoy vanne na poristost' kompozita pri mokrom sposobe namotki [The effect of the viscosity of the binder in the impregnation bath on the porosity of the composite with the wet winding method].

[5] Namitokov K.K., Ovchinnikov S.S., Savvo N.M. Primeneniye (1987) UF i IK izlucheniy v tekhnologii polimerov [UV and IR radiation in polymer technology] // Primeneniye plastmass v stroitel'stve i gorodskom khozyaystve. p. 90-91.

[6] Tsaplin A.I. Bochkarev S.V., Mordvin A.P. (1986) Dinamika elektronno-luchevogo nagreva stekloplastikovogo tsilindra, vrashchayushchegosya na opravke [Dynamics of electron beam heating of a fiberglass cylinder rotating on a mandrel] // Mechanics of Composite Materials, №2, p. 359361

[7] Manko T.A., Husarova I.A., Romenska O.P. (2019). Ispol'zovaniye infrakrasnogo nagreva pri izgotovlenii izdeliy iz polimernykh kompozitsionntkh materialov [The use of infrared heating in the manufacture of products from polymer composite materials] // Bulletin of Dnipropetrovsk University. Series: Space rocket technology, № 24/19, p.120-123.

[8] Dzhon G. Perri (1969). Spravochnik inzhenera-fizika [Handbook of a physical engineer], $640 \mathrm{p}$.

[9] Mukhamadeyev I.G. (2007). Algoritmy vychislitel'noy matematiki. Kurs lektsi [Algorithms of computational mathematics. Lecture course].

\section{МАТЕМАТИЧНЕ МОДЕЛЮВАННЯ ПРОЦЕСУ НАГРІВУ КОМПОЗИТНОЇ КОНСТРУКЦІЇ ІНФРАЧЕРВОНИМ ВИПРОМІНЮВАННЯМ Рожковський В.Ф., Манько Т.А., Роменська О.П., Зевако В.С.}

\section{Реферат}

Існуючі виробничі потреби сучасного ринку пред'являють все більш зростаючі вимоги до характеристик сучасних матеріалів для розширення області їх застосування в більш жорстких і екстремальних умовах з одночасним пошуком економічно вигідних виробничих процесів отримання готових виробів.

В аерокосмічній техніці широке застосування отримали полімерні композиційні матеріали (ПКМ) на основі вуглецевих волокон. Унікальні властивості композиційних волокнистих матеріалів визначаються, в першу чергу, високими механічними властивостями самих волокон.

Відомо, що на характеристики ПКМ впливає технологічний режим виготовлення. Традиційно, вироби з вуглецевих волокон отримують методами намотування або викладки на формуючу оправку з подальшою полімеризацією в спеціальних печах. Такі методи є багатостадійними, трудомісткими і вимагають високих енергетичних витрат.

Пошук шляхів поліпшення традиційних методів виготовлення вуглепластиків і підвищення реалізації властивостей вихідних матеріалів, привели до використання інфрачервоного нагріву. Нагрів пропонується застосовувати в процесі намотування і полімеризації вуглепластика. Завдяки застосуванню нагріву в процесі намотки зберігається постійною в'язкість матриці (сполучного), тим самим забезпечується рівномірність просочення наповнювача. Протягом впливу інфрачервоного випромінювання на наповнювач і матрицю відбуваються процеси їх затвердіння. Ці процеси відбуваються завдяки впливу квантів енергії $\mathrm{hx}$ на розвиток хімічних реакцій між макромолекулами, тобто виникають фотохімічні процеси взаємодії. 3 метою доотвердіння і зняття внутрішніх напружень в вуглепластика інфрачервоний нагрів пропонується застосовувати в процесі полімеризації. Таким чином, застосування інфрачервоного нагріву дозволяє скоротити час виготовлення, а також завдяки більш рівномірному прогріванню, збільшується однорідність мікроструктури затверділого вуглепластика.

В роботі, з метою уточнення режиму полімеризації вуглепластикової циліндричної конструкції, проводили математичне моделювання процесу нагріву композиту (циліндра) інфрачервоним випромінюванням при використанні методу кінцевих різниць. 
За допомогою математичного моделювання встановлено, що при заданих режимах полімеризації під впливом інфрачервоного нагріву вуглепластиковий циліндр протягом 120 хвилин досягне повністю затверділого стану. Дані розрахунку підтверджені аналізом ступеня полімеризації фрагмента вуглепластика, вирізаного з циліндра, затверділого під впливом інфрачервоного нагріву. Значення ступеня полімеризації вуглепластика при використанні інфрачервоного випромінювання при затвердінні становить 95-96 \%.

\section{Література}

1. Михайлин Ю.А. Конструкционные полимерные композиционные материалы. СПб.: Научные основы и технологии, 2008. 822 с.

2. Коваленко В.А., Кондратьев А.В. Применение полимерных композиционных материалов в изделиях ракетно-космической техники как резерв повышения ее массовой и функциональной эффективности. ISSN 1727-7337. Авиационно-космическая техника и технология, 2011, №5 (82), c.14-20

3. Цаплин А. И., Бочкарев С. В. Нестационарное температурное поле вращающегося стеклопластикового цилиндра, облучаемого параллельным пучком электронов // Механика композитных материалов, 1980, №2, с. 304-307.

4. Комков М.А., Тарасов В.А. Влияние вязкости связующего в пропиточной ванне на пористость композита при мокром способе намотки. М.: Изд-во МГТУ им. Н.Э. Баумана, 2014. $327 \mathrm{c}$.

5. Намитоков К.К., Овчинников С.С., Савво Н.М. Применение УФ и ИК излучений в технологии полимеров // Применение пластмасс в строительстве и городском хозяйстве: Тез. докл. 2 Республ. научно-техн. конф. Харьков, 1987. ч. 1.с. 90-91

6. Цаплин А. И., Бочкарев С. В., Мордвин А.П. Динамика нагрева пучком электронов стеклопластикового цилиндра, вращающегося на оправке // Механика композитных материалов, 1986, №2, c. 359-361.

7. Манько Т.А., Гусарова И.А., Роменская О.П. Использование инфракрасного нагрева при изготовлении изделий из полимерных композиционніх материалов. Вісник Дніпропетровського університету. Серія: Ракетно-космічна техніка, номер 24, вип. 19, с.120-123.

8. Джон Г. Перри. Справочник инженера-физика.Т.1. перевод с четвертого английского издания под общей редакцией акад. Н.М. Жаворонкова и чл.корр. П.Г. Романкова. Изд. Химия, $1969,640 \mathrm{c}$.

9. Мухамадеев И.Г. Алгоритмы вычислительной математики. Курс лекций. 2007. 